\title{
Family Approach of Older People with Major Neurocognitive Disorder: Experiences and Perceptions from the Psychogerontological Clinical Practice
}

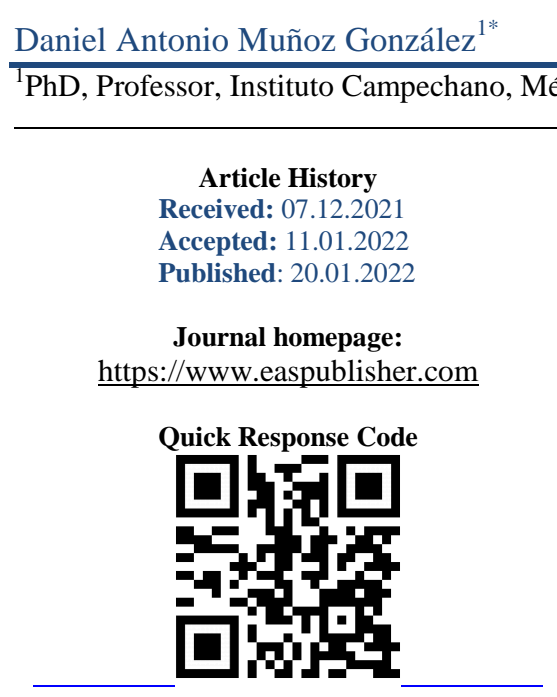

Abstract: The approach to older adults with major neurocognitive disorder constitutes a challenge for families, this due to the lack of information to carry out this type of specialized care, and the scarcity of health professionals trained to facilitate an approach and Professional guidance on mental health in old age. In this sense, psychogerontological clinical practice is established today as an interdisciplinary field of study, due to the exhaustive knowledge about the sciences of aging and clinical psychology, for the evaluation, detection, rehabilitation, orientation and promotion of mental health with older people, family members and caregivers. Objective: To understand the experiences and perceptions of family members who care for older adults diagnosed with major neurocognitive disorder. In such a way, it allows to explore, understand and interpret about the knowledge about the appropriate approach, the risks of patient care and decision-making for coping. Materials and methods: a phenomenological-oriented qualitative study was carried out in an integral medicine unit, through the design and application of semistructured interviews and observations of ten caregivers who attended the Psychogerontology service. Results: The informants stated that they did not have the necessary information to carry out adequate care for their relatives. However, the need for more professionals and social institutions to receive information is necessary. In this sense, they perceive their quality of life as poor, since they present the signs and symptoms of caregiver syndrome. Conclusions: Psychogerontological clinical care favors effective intervention in the approach to major neurocognitive disorder.

Keywords: Family approach, older adults, major neurocognitive disorder, clinical psychogerontology.

Copyright ( ) 2022 The Author(s): This is an open-access article distributed under the terms of the Creative Commons Attribution 4.0 International License (CC BY-NC 4.0) which permits unrestricted use, distribution, and reproduction in any medium for non-commercial use provided the original author and source are credited.

\section{INTRODUCTION}

The mental health of older adults is associated with the sense of well-being that this age group maintains, in relation to their individuality, family, social relationships and the ability to adapt to the environment. According to Tello, Alarcón and Vizcarra (2016), there are various biological, psychological and social factors that significantly impact the mental health of this age group, such as grief, retirement, disability and various medical illnesses.

That is why many of the older adults may experience, at some point in their lives, social exclusion and isolation; associated with the loss of a loved one, delicate health and changes in living conditions, such as entering a nursing home (Ibesco, 2017).

It is known that when the stage of old age is reached, older adults are associated with negative stereotypes such as illness, disability and even vulnerability. Family and society are factors that condition this situation, which predisposes the elderly to depression and other psychopathological disorders. According to Escalona and Ruiz (2016), older adults in the community present mental health problems such as somatization, obsessions, anxiety and depression. All these disorders affect the quality of life of those who are experiencing such as their family, because these psychopathological disorders are accompanied by physical discomfort, anguish, fear, worries and hopelessness; being able to affect men and women equally.

According to Mira (2017), older adults can suffer from mental disorders that must be known, since more than $20 \%$ suffer from some neuropsychiatric disorder such as dementia and depression. The treatment of both diseases primarily requires family 
attention, care and support in order to guarantee the biopsychosocial well-being of the elderly.

In such a way, that clinical psychogerontology is a timely area of care for older people with major neurocognitive disorder and guidance to their families. In this vein, the work of the psychogerontologist is to evaluate, identify, design strategies, investigate and implement care programs that allow addressing cognitive and psycho-affective disorders in gerontological care modules, comprehensive mental health centers, day centers for the elderly, psychiatric hospitals and community centers for social development, representing a specialty in the health area of utmost importance in this contemporary society.

\section{The Major Neurocognitive Disorder: a Conceptual, Epidemiological and social approach}

Major neurocognitive disorder is defined by the WHO (2017) as a syndrome characterized by impaired memory, intellect and higher brain functions, which affects behavior and the ability to carry out life activities daily. This disease does not represent a consequence that characterizes aging, but it mainly affects the elderly population.

The major neurocognitive disorder will affect 76 million people in the world in 2030 (Aguilar, 2017), which represents that there will be 5.8 new cases of people with dementia per year, which is why monitoring, care and follow-up should be offered that To improve the quality of life of older women and men with dementia. In Mexico, the Alzheimer and other dementias action plan was agreed in 2014, promoted by the National Institute of Geriatrics and the Ministry of Health, seeking to take concrete actions in the care of the disease. At present, there is still no state public policy on mental health that promotes care for people with dementia.

The World Health Organization (WHO) recognized Alzheimer's and dementias as a public health priority. Consequently, PAHO adopted a regional plan to improve and expand care for older adults with dementia; prevent and delay their dependency and functional deterioration, and increase research on the subject.

Data from Sosa (2014) report that Alzheimer's disease is the main form of dementia with a frequency of 50 to $70 \%$ of all dementias, the prevalence of dementia grows exponentially from 65 to 85 years, doubling every 5 -6 years and stabilizing from 85-90 years. Women have a higher risk of suffering from Alzheimer's dementia, while men have vascular dementia. If you have a first-degree relative with dementia, the risk of developing it is four times higher.

Based on Llibre, J., Díaz, J., Rodríguez, A., Guartazaca, E., Peñalvier, A., Rousseaux, E., Estelles,
M. (2018) the educational level and the lifestyles are psychosocial determinants that predispose the appearance of dementias and their development. That is why, given the influence of said determinants and the health status of the population, it is essential to carry out research on the correlation that exists between these two variables and thereby contribute to the design and application of intervention strategies community that has a favorable impact on the quality of life of the elderly.

The WHO (2016) has recognized the difficulty of having enough specialists to attend to each case of dementia. For this reason, the strategy is to ensure that not only the doctor, but all top-level health personnel are trained to care for patients and their families. In Campeche every day there is a new case of a patient with some type of dementia, which affects the family, the economy and health expenses and currently there is no government public policy that provides strategies for their care.

\section{Depression in older adults and its association with major neurocognitive disorder}

According to Sotelo, Rojas, Sánchez and Irigoyen (2012), depression is the affective disorder that has the greatest impact on people over 60 years of age and female, characterized by the presence of sadness, concentration and problems with conciliation of the dream.

That is why, according to the WHO (2011) reviewed in Durán, T., Aguilar, R., Martínez, M., Rodríguez, T., Gutiérrez, G, Vázquez, L (2013), Depression generates loss of interest in the execution of activities of daily life, guilt, lack of concentration and generalized fatigue, which if not identified in a timely manner, negatively aggravates the quality of life, being a predisposing factor in the development of cognitive deterioration; in addition to being a risk factor for committing suicide.

Depression in older adults is sometimes associated by health personnel and by family members themselves, as a condition of the aging process. However, Bolaños, M and Helo F. (2015) mention that this disease does not receive adequate attention and treatment and, as a consequence, predisposes the elderly person to deterioration in functionality; that decreases their quality of life and increases the expense and use of health services.

In the area of gerontology, geriatrics and clinical psychology, the geriatric depression scales represent a means for screening depressive symptoms in older adults, being validated and used both in clinical practice and in research, to associate this disease with disability and dysfunction (Harris, T., Cook, D., Victor, C. (2006). 
Similarly, there is an association between cognitive decline and depression. This is due to the fact that in addition to being a risk factor for cognitive deterioration, it is also a manifestation of the disease itself. That is why the comprehensive gerontological assessment is intended to identify signs and cognitive deficiencies that differ in an older adult; from depression to just accelerated aging caused by your lifestyle.

As previously discussed, the family influences the quality of life of older adults, in addition to being directly or indirectly responsible for providing wellbeing or negatively affecting their personal development. Based on Chavarría, R., Ochoa, L., Suazo, N., Morales, R., Espinoza, M., Rodríguez, B., Flores, J., Rivas, K., and Guevara, J. (2011) mention that older adults who maintain a close family bond are those with the lowest incidence of suffering from signs and symptoms of depression. Similarly, religion is associated as a resource to which.

In conclusion, the timely identification of depressive symptoms in older adults, by the family and the health personnel assigned to their care, will allow them to be given adequate treatment according to their needs in a timely manner. In the same way, it will reduce the risk of dependency in the elderly and reinforce the positive perception of their quality of life.

\section{Family, old age and major neurocognitive disorder}

The WHO defines the family as the set of members who are related to each other, being this union by marriage, blood and even adoption. For Serrano (2013) the family plays an important role in the elderly. This is due to the fact that it generates a general wellbeing and in the health and social relationships of this age group, thereby allowing active and healthy aging. On the other hand, it should be mentioned that there is still a lack of information that provides families with adequate care and attention to the elderly, as mentioned by Arroyo and Ribeiro (2011) due to the lack of social support policies for the care of old age, the family assumes a difficulty to face the care and diseases of the elderly, representing an emotional and social burden for families, health services and nations.

Older adults are associated with negative influences such as crises arising from the death of their partner, caring for a child, illness and accidents that cause invalidity or disability. Similarly, there are crises due to psychosocial factors such as loss of economic status or home (Placeres, León and Delgado 2011).

It is important to mention that despite the fact that old age should be a time of joy for older adults, due to the culmination of their work relationships and responsibilities towards their children, it is known that the crises represented by some type of mourning by As a reason for the aforementioned factors, it represents a significant offense towards the elderly population, since fears, loneliness and even death are manifested (APA, 2018).

The family and the elderly person can experience hopelessness and alterations in behavior and moods as a result of this set of losses, which if not maintaining effective communication between both parties and making decisions together, can be the triggering factor for the loss. Onset of depression and emotional decline in the family.

According to Flores, Huerta, Herrera and Alonso (2011) depressive symptoms represent a health problem for older adults that impacts their quality of life and that of the family. Given these facts, family members at some point may commit some type of abuse towards older adults. Gutiérrez (2013) cited by Llanes, López, Vázquez and Hernández (2015) mention that retirement from work is a factor of changes in the family relationships of the elderly person. It is difficult for the elderly person to have an active participation in the home and that is why they begin to experience social isolation and the loss of the roles they performed. It is important to say that this experience is more of a psychosocial factor that can turn into vulnerability, to a biological factor of an individual.

Major neurocognitive disorder represents the loss of social and family roles of the sufferer, as well as a biopsychosocial risk factor for family members, caregivers and the patient's environment. In psychogerontological clinical practice, these manifestations that family members request are often attended to and therefore represent a timely area of action.

\section{Materials ANd Methods}

A qualitative study with a phenomenological approach was carried out to understand the experiences and perceptions of family members who care for older adults diagnosed with major neurocognitive disorder. The research was carried out in the Psychogerontology service of the Comprehensive Medical Unit, located in the city of San Francisco de Campeche, between March and November of the year 2021. In this sense, the importance of this project lies in the fact that the relatives requested to receive guidance In order to adequately address their patients with said disease, however, the services offered in the field of Psychogerontology are private. In such a way, that this experience allowed to propose the guidelines to facilitate the integration of the family members to the treatment of the patient. It should be mentioned that the informed consent of the study subjects of this research was requested in order to carry out the previously designed semi-structured interviews. Likewise, 10 female caregivers and daughters of the patients attended participated, noting that the men reported refusal at the time of offering to be part of this experience. The 
interviews were conducted individually within the office. Likewise, field notes based on family members' observations were used. The duration of each interview was an hour and a half on average. Finally, the objective of the interviews and observations was to explore, understand and identify knowledge about the appropriate approach to patients, the biopsychosocial risks of care and leadership in making timely decisions for the benefit of the quality of life of the couple caregiver - patient.

\section{Analysis and presentation of findings}

The coding of the individual interviews with the family members was carried out by the researcher, who organized the information assigning a pseudonym to each informant (Fam_1_Pérez) in order to protect the identity of the family members who decided to participate in the research. Once the coding had been carried out, the analysis of the interviews of each of the participants was carried out in 10-minute intervals. In this sense, the fragments related to the objectives of the study were transcribed, classifying said information from three perspectives: a) exploring knowledge about the approach of older adults with major neurocognitive disorder, b) understanding and identifying psychosocial and health risks experienced by caregivers and c) interpreting the aspirations of caregivers towards empowerment based on their experiences and perceptions. The coding and analysis of the themes were carried out using a matrix of categories of qualitative analysis and the participants were invited to know the important findings of the study.

\section{RESULTS}

10 relatives were interviewed, all of them voluntarily at the time of participating in the study. The 10 relatives were women, since the men expressed no interest in participating. All family members reported caring for older adults with major neurocognitive disorder, the ages of the family caregivers were between 45 and 60 years old. In this sense, mention is made of the three areas to work in this research: a) knowledge about the approach of the elderly person with neurocognitive disorder, b) perception of the risk of care and c) Coping with the family member. When conducting the interview, (9/10) relatives agreed that they did not know how to take care of and attend to their patients in a timely manner.

\section{Knowledge of family members about the care of elderly people with major neurocognitive disorder}

Family members reported timely ignorance about the care of older people with major cognitive disorder, in such a way that that is why they went to the psychogerontology service to receive care. On the other hand, they expressed physical and emotional fatigue, when referring is a task of great commitment that not everyone understands due to lack of knowledge on the subject.
"Pss the truth I never thought that this disease would happen to my mother, I find it somewhat difficult because I don't know how to treat it when it starts in its days of crisis" (fam_1_Gómez). "I had heard of senile dementia, I thought that happened to people when they were very old, my mom was always active so I don't understand what happened"(fam_2_Pérez). "I knew that my grandmother suffered from a dementia disease and my mother struggled a lot with that situation, perhaps that made her very tired and that is why now she is as she is and I don't know what to do in this situation that gets more difficult every day" (fam_3_Solis ) "Still in December she celebrated Christmas with us and my mother was fine, if I started to notice she forgot things, but I didn't pay attention to why that happens to all old people. The truth is, I don't know how to take care of her and for that reason I go to this clinic "(fam_4_Calderón)" sometimes I think it is on purpose that she forget things, she was always strong in character and she got away with it to achieve things , but for that I come to the doctor to know the truth how to treat her and not to blackmail me "(fam_5_lópez)" I already feel tired of this situation, I do not sleep, she does not let me go out and every so often she calls me to sleep with her, I don't know how to tell her that I'm already very tired, but she's my mother and I have to take care of her, I ask for the help of the doctors to be able to deal with this situation "(fam_6_Vázquez)" they told me that they treated old people with problems at the clinic by heart and that's why I brought my mother, the truth is she is retired and with that little money we pay the service, but we need it in order to give her a better treatment, since my brothers are unaware of all this that we are experiencing and I am still informing "(fam_Villamonte_7)" in my house They do not understand that my mother is sick and I am tired of being always between her and my children, it is difficult for them to understand and I would like to know what else I can do to calm the situation a bit "(fam_Caamal_8)" I do not know how much more money I have I have to spend on my mother because we already did a lot for her, sometimes I think she does not understand why the more we help her the more curses she tells me, the truth is that makes me feel upset and I would like to calm a little the stress that I have "(fam_Rodríguez_9)" since I started with memory problems more than a year ago, I have been reading about the disease in order to understand it better, coming to therapies has helped me a lot to understand every day so my mother is passing "(fam_González_10).

En este rubro, los familiares concluyeron y coincidieron en que es costoso que este tipo de enfermedades se atiendan en el sector de salud privado, ya que para atender la enfermedad se tiene que visitar de varios especialistas sanitarios, por lo que consideran oportuno el gobierno fomente la asistencia pública a este sector de la población que tanto lo necesita. 
In this area, the relatives concluded and agreed that it is costly for this type of disease to be treated in the private health sector, since several health specialists have to be visited in order to treat the disease, which is why they consider appropriate the government to promote public assistance to this sector of the population that so badly needs it.

\section{Family members' perception of the health and psychosocial risk of caring for older people with major neurocognitive disorder}

The 10 women interviewed express in a very specific way that since the beginning of care for their mothers as a result of this disease, they have begun to experience health and emotional problems that day by day wear out their spirits to face this situation with energy.

"Sometimes I feel like I can't take it anymore, I'm the one who's going to end up the sickest" (fam_1_Gómez) "I don't want to leave the house anymore, my mother absorbs me all the time" (fam_2_Pérez) "I had to go to a caregiver help me with my mother, I can't by myself, I'm getting sick "(fam_3_Solis)" I've run out of money, without strength and no longer wanting to do anything, this matter is tiring "(fam_4_Calderón)" my brothers don't help me with Nothing, all the expenses and efforts were made by me, I am aware that it is my mother but I can't take it anymore "(fam_5_lópez)" Sometimes this situation is desperate because I have neglected my family for dedicating myself to my mother, my children are still adolescents and I feel that they require me, but my mother has no one and that makes me feel bad "(fam_6_Vázquez)" she is my mother, she is tired but there is no other "(fam_Villamonte_7)" I currently look older than I am, I am 58 years old and I already look much older than my own mother, my eye trembles a lot and I feel anxious about most of the time "(fam_Caamal_8)" my children already told me that I have changed a lot since I took care of my mother, the truth is I am getting sick "(fam_Rodríguez_9)" I would like to receive help because the one who will end up dying first will be me "fam_González_10).

In this sense, it is important to design intervention strategies in clinical psychogerontology, which contemplate the approach of relatives with a view to facilitating resilience and emotional care to face this type of problems that represent psychosocial risk factors within the environment, reducing the quality of life and patient care.

\section{Family decision-making for coping}

In this area, the vision and individual strategies of the family members to face the care of the elderly with neurocognitive disorder stand out. In this sense, the (10) informants interviewed are optimistic and state that the situation has to be approached with professionalism and faith, despite the negative circumstances that may arise along the way.

"I have faith in God, he will help us to face the problem" (fam_1_Gómez) "although my other family members do not want to, I am thinking of hiring a nurse to help me with my mother" (fam_2_Pérez) "I am confident that our Lord Jesus Christ will help us with this problem "(fam_3_Solis)“" My mother did a lot for us, now my brothers and I have to give it back without feeling fear "(fam_4_Calderón)“" my children and my husband despite the problem that it implies, every day they understand that I need support " (fam_5_lópez) "I have faith, God will give me the strength so that my mom can improve" (fam_6_Vázquez) "this situation despite everything, has made my brothers unite little by little" (fam_Villamonte_7) "it's tired but with the help from my God we are going to move forward "(fam_Caamal_8)" I only ask the little virgin to give me a lot of strength to continue on the road "(fam_Rodríguez_9)" Maybe today it will be for her and tomorrow for me, that my children will be an example of tomorrow "fam_González_10).

That said, mutual aid or self-help groups represent an important strategy, since it allows family members to be integrated from the therapeutic approach and allows them to discharge all those negative emotions that may be experiencing as a result of exhaustive care, in the same way, social support networks favor optimism and supportive relationships with their environment for optimal coping.

\section{DEBATE}

Daughters are the ones who mainly allocate efforts for the care of parents with major neurocognitive disorder. In this sense, family care is mainly made up of women, they participate within this family model and are typical of Western cultures (Bazo, 1998), however, contemporary societies have included women within the world of work and new marriages; That has made that day by day this type of activity is lost.

Similarly, family care has been based on the time and work of women, which is supposed to be free in economic terms. It is currently understood that the decrease in family size, the incorporation of women into the world of work, their higher levels of education, the increase in divorces, new marriages, and the changes that all this entails in traditional family models in the so-called Western societies, endangers the continuity of such care. In this sense, Kredler (2018) refers that informal care is mostly provided by the main spouse and that they are mainly women of working age and still living in the parents' home. For this reason, the provision of care and economic resources are combined to facilitate a more dignified life.

On the other hand, the interviewees mentioned that they did not have the help of their siblings, many 
manifested apathy towards the mother's situation with the disease, or only provided part of the money for care, without the commitment to get involved with the disease. Situation. In this vein, Álvarez (2015) expresses "The best and the only thing that works is to speak clearly with your family. But seriously, not in passing. In other words, you have to have a couple or family reunion and the theme of the day is: "our parents and grandparents." What do we do? How do we organize ourselves? How can we help?" Although it is true, the daughters expressed feeling desperate in the psychosocial and economic plane and for fear of not causing discomfort, they did not express their true feelings about the care. For this reason, guidance is important to establish coping strategies to involve the family in a situation as delicate as that of the caregiver of an elderly person, who is no longer functional and requires a lot of understanding and family affection.

Finally, the interviewees reported feeling optimistic despite the circumstances, as they trust that with faith and effort they will be able to move forward. At this point, mutual aid groups and social support networks represent a significant impact in terms of social, psychological and spiritual services, to face the reality of family members in association with care. In this sense, Juárez et al. (2021) refers that, with the adequate training of the health teams destined for mutual aid groups, they will represent an ideal space for emotional support and contribute to the well-being of the participants. For this reason, therapeutic sessions in clinical psychogerontology, meeting with friends, family support and spirituality, represent protective factors to consider to maintain a better quality of life.

\section{Conclusions}

It is concluded, referring to the need to promote prevention, promotion and education in health, in matters of neurodegerative diseases such as major neurocognitive disorder and old age, in this sense, multidisciplinary and interdisciplinary teams should join forces to privilege scientific study and professional care for this age group. As women are the main facilitators of this care for patients, equality and shared responsibility between both sexes must be promoted to provide equitable and ethical care. However, it is necessary that social and health services for older adults become more public in nature, since access may be limited for a society that barely survives on the minimum wage. Finally, caregivers have to take care of themselves. For this reason, it is recommended not to take personally the behaviors that patients may be presenting, such as behavioral changes that lead to insults, violence and frustration. Remembering that the appropriate treatment for relatives and patients are both pharmacological and non-pharmacological, in this way, it will contribute to dignify the quality of life of those who now do not remember things.

\section{REFERENCES}

- Aguilar, F. (2017). Amenaza Alzheimer a 76 millones de personas para el año 2030. 10 de febrero del 2017, de El sol de México Sitio web: https://www.elsoldemexico.com.mx/mexico/45545 6-amenaza-alzheimer-a-76-millones-de-personaspara-2030

- Álvarez, M. (2015). "Cuando toca cuidar a los padres siempre hay hermanos con mucha jeta" disponible en: https://www.abc.es/familia-padreshijos/20151013/abci-mujeres-generacionsandwich-201510051617.html

- American, P. A. (2018). El cuidado de las personas mayores: más que solo cuidar de los padres. Recuperado en: http://www.apa.org/centrodeapoyo/cuidado.aspx

- Arroyo, M., Ribeiro, M. (2011). El apoyo familiar en adultos mayores con dependencia: tensiones y ambivalencias, Revista Ciencia UANL, 14(3) 297 305

- Bazo, M. (1998). El cuidado familiar en las personas ancianas con enfermedades crónicas: el caso de los pacientes con enfermedad de Alzheimer. Rev Española de Geriatría y Gerontología. Disponible en: https://www.elsevier.es/es-revista-revistaespanola-geriatria-gerontologia-124-articulo-elcuidado-familiar-personas-ancianas-13005972

- Bolaños, M., Helo, F. (2015). Depresión en el adulto mayor costarricense y su relación con la autopercepción del estado de salud y desempeño funcional. Revista Clínica de la Escuela de Medicina UCR - HSJD, 5(4) 78-87.

- Chavarría, R., Ochoa, L., Suazo, N., Morales, R., Espinoza, M., Rodríguez, B., Flores, J., Rivas, K., Guevara, J. (2011) Depresión en adultos mayores de 60 a 75 años en San Lorenzo, Valle. Revista Facultad de Ciencias Médicas, 8(2) 9-22.

- Duran, T., Aguilar R., Martínez, M., Rodríguez, T., Gutiérrez, G., Vázquez, L. (2013). Depresión y función cognitiva de adultos mayores de una comunidad urbano marginal. Revista de enfermería universitaria, 10(2); 36-42.

- Escalona, B.Y., Ruiz, A. (2016). Salud mental y funcionamiento familiar en adultos mayores de Melchor Ocampo, Estado de México. Revista Psicología Iberoamericana, 24(1) 38-46.

- Flores, S., Huerta, Y Herrera, O., Alonso, O. (2012). Factores familiares y religiosos en la depresión de adultos mayores. Journal of Behavior, Health \& Social Issues, 3(2) 89-100.

- Harris, T., Cook, D., Victor, C. Onset and persistence of depression in older people - results from a 2-year community follow-up study. Age and Ageing, 35(1) 25-32.

- Ibesco Social Care. (2017). Estereotipos asociados a las personas mayores. Recuperado en http://ibescosocial.com/PDFS/estereotipos.pdf 
- Juárez, C. (2021). Los Grupos de Ayuda Mutua como posible estrategia de apoyo emocional para personas indígenas que padecen diabetes. Rev Salud Pública de México. Disponible en: https://saludpublica.mx/index.php/spm/article/view $/ 11580$

- Kredler, M. (2018). ¿Quién cuida a los ancianos en situación de dependencia? Una comparativa internacional. Disponible en: https://www.fundacionareces.es/fundacionareces/es /comunicacion/blog/quien-cuida-a-los-ancianos-ensituacion-de-dependencia-una-comparativainternacional.

- Llibre, J., Díaz, J., Rodríguez, A., Guartazaca, E., Peñalvier, A., Rousseaux, E., Estellés, M. (2018). Determinantes del estado de salud de la población y su influencia en el desarrollo de los trastornos cognitivos. Revista Cubana de Salud Pública, 44(1); 1-14.

- Mira, C. (2017). Salud mental en adultos mayores: Por qué el bienestar emocional es tan importante en esta etapa. Revisado en Infobae tendencias. Disponible en https://www.infobae.com/salud/2017/10/10/saludmental-en-adultos-mayores-por-que-el-bienestaremocional-es-tan-importante-en-esta-etapa/

- Tello, T., Alarcón, R., Vizcarra, D. (2016). Salud mental en el adulto mayor: trastornos neurocognitivos mayores, afectivos y del sueño. Revista Peruana de medicina experimental pública, 33(2) 342-350.

- Organización mundial de la salud. (2011). La falta de inversión en atención a la salud mental a escala mundial. Recuperado en: http://www.who.int/mediacentre/news/notes/2011/ mental_health_20111007/es/

- Organización Mundial de la Salud. (2016). ¿Qué es la promoción de la salud? Recuperado en: http://www.who.int/features/qa/healthpromotion/es/

- Organización Mundial de la Salud. (2017). Demencia. Recuperado en http://www.who.int/mediacentre/factsheets/fs362/e s/

- Placeres, J., De león, L., Delgado, I. (2011). La familia y el adulto mayor, Revista médica electrónica, 33(4), 472-483.

- Sosa, A. (2014). "Epidemiología de las Demencias", Instituto Nacional de Geriatría, México, Sitio web www.geriatria.salud.gob.mx, Consultado el 11 de agosto de 2021 17:00 pm, Disponible en http://www.geriatria.salud.gob.mx/descargas/23. pdf

- Serrano, A. (2013). El papel de la familia en el envejecimiento activo. Instituto internacional de estudios sobre la familia. Recuperado en http://fiapam.org/wpcontent/uploads/2013/06/Informe20132.pdf

- Sotelo, A., Rojas, J., Sánchez, C., Irigoyen, A. (2012). La depresión en el adulto mayor: una perspectiva clínica y epidemiológica desde el primer nivel de atención, Archivos en Medicina Familiar, 14(1) 5-13.

Cite This Article: Daniel Antonio Muñoz González (2022). Family Approach of Older People with Major Neurocognitive Disorder: Experiences and Perceptions from the Psychogerontological Clinical Practice. EAS J PsycholBehavSci, 4(1), 8-14. 